\title{
Raziskovanje izvora kamna za črnilo iz Zbirke Alme Karlin*
}

\author{
Tina BERDAJS**
}

\section{Izvleček}

$\mathrm{V}$ različnih slovenskih muzejih in zasebnih zbirkah hranijo več zbirk vzhodnoazijskih predmetov, od katerih so $\mathrm{v}$ zadnjih letih nekateri postali objekt večjega znanstvenega zanimanja. $V$ prispevku je predstavljen primer kamna za črnilo iz zbirke osebnih predmetov Alme M. Karlin (1889-1950), ki jo hrani Pokrajinski muzej Celje. Pred to raziskavo so bile osnovne informacije o predmetu iz omenjene zbirke redke, konkretni podatki o njegovi zgodovini pa pomanjkljivi. $S$ to študijo primera je bila določena provenienca in osnovni podatki, hkrati pa predstavljen tudi metodološki aparat, uporabljen za raziskovanje in končno potrditev izvora obravnavanega predmeta. Osrednji del članka se osredotoča na raziskovanje pomena na kamnu izrezljanega pečata in na razrešitev ročno napisanega zapisa na spodnji strani predmeta. Oba zapisa sta tudi postavljena v širši kulturnozgodovinski kontekst vzhodnoazijske regije in v kontekst potovanja Alme Karlin.

Ključne besede: Zbirka Alme Karlin, provenienca predmetov, kamen za pridobivanje črnila, pečat

\section{Researching the Origins of an Ink Stone from the Collection of Alma M. Karlin}

\section{Abstract}

There are several collections of East Asian objects kept in various Slovenian museums and private collections, some of which have become the subject of greater scholarly interest in recent years. This paper is a case study of an object-an ink stone--from the collection of personal objects acquired by Alma M. Karlin (1889-1950), now preserved at the Celje Regional Museum. Prior to this survey, there was little basic information about the object from the collection, and concrete data on its history was lacking. This case study determined the object's provenance and basic data, and at the same time illustrates a methodological approach which was used for research and final confirmation of the origin of the object in question. The main part of the paper focuses on research into the meaning

* Pričujoči prispevek je nastal v okviru projekta Vzhodnoazijske zbirke v Sloveniji: vpetost slovenskega prostora v globalno izmenjavo predmetov in idej z Vzhodno Azijo (2018-2021) (št. J7-9429), ki ga finančno podpira Javna agencija za raziskovalno dejavnost Republike Slovenije (ARRS).

** Tina BERDAJS, doktorska študentka Oddelka za azijske študije,

Filozofska fakulteta, Univerza v Ljubljani, Slovenija.

Elektronski naslov: tina.berdajs[at]ff.uni-lj.si

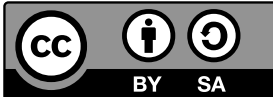


of the carved seal mark and deciphering of a handwritten inscription, both of which are located on the underside of the ink stone. Some of the problems of the research process were resolved through methods of analysis and comparison of photographic material, and the research revealed previously unknown data that helped to determine the correct place of origin of the ink stone, as well as a more precise timeframe in which the object was created. Both inscriptions were placed in the wider cultural and historical context of the East Asian region, as well as in the context of Alma Karlin's travels.

Keywords: Alma Karlin's collection, object provenance, ink stone, seal mark

\section{Uvod}

Alma Maximiliana Karlin (1889-1950) je brez dvoma ena največjih svetovnih popotnic z območja današnje Slovenije. Kot mlada ženska se je kmalu po dopolnjenem tridesetem letu starosti,24. novembra 1919, sama odpravila iz rodnega Celja na študijsko potovanje okoli sveta. S seboj je vzela kovček, pisalni stroj, nekaj denarja in neustavljivo željo po odkrivanju novih dežel in spoznavanju novih ljudi ter učenju njihovih jezikov in odkrivanju njihove kulture, običajev, načinov življenja. Med osemletnim potovanjem je zbirala najrazličnejše predmete ${ }^{1}$, ki dandanes sestavljajo Zbirko Alme Karlin; ta obsega 840 predmetov $^{2}$, hrani pa jo Pokrajinski muzej Celje ${ }^{3}$.

Celotna zbirka predmetov Alme Karlin odraža tudi naravo njenega potovanja in osvetljuje pogoje, v katerih je pisateljica potovala; kadar ji je lastni ekonomski položaj omogočal, je predmete kupovala, sicer je pogosto zbirala, kar je lahko: darila, školjke, minerale, cvetlice. Po vrnitvi s potovanja 28. decembra 1927 je zbirko predmetov razstavljala in uporabljala v svojem domu, po njeni smrti leta 1950 pa je lastnica zbirke postala njena edina dedinja, dobra prijateljica Thea Schreiber Gammelin (1906-1988)4. Slednja se je sedem let po Almini smrti odločila,

1 Predmete, ki jih je zbirala na potovanju, je Alma Karlin večinoma pošiljala domov, nekatere pa je najprej nosila s seboj in jih šele zatem odposlala. V posebnem zvezku je imela tudi seznam, kdaj in komu je različne predmete poslala, nekatere predmete je omenjala tudi v svojih potopisih Samotno potovanje in Urok Južnega morja (Trnovec 2015, 57).

2 Zbirka predmetov Alme Karlin, ki jo hrani Pokrajinski muzej Celje, še ni zaključena, kar pomeni, da se vanjo še vedno lahko dodajajo oz. vključujejo novi predmeti (Trnovec 2015, 58).

3 Pokrajinski muzej Celje v Zbirki Alme Karlin hrani različne predmete, ki jih je Alma zbirala med svojim potovanjem, celotna zapuščina pa je veliko bolj obsežna, razdrobljena in ni v celoti dostopna javnosti. Poleg omenjenega muzeja se deli zapuščne nahajajo še v Narodni in univerzitetni knjižnici v Ljubljani, Osrednji knjižnici Celje, Muzeju novejše zgodovine Celje, zasebnih arhivih in drugje (Trnovec 2015,58).

4 Thea Schreiber Gammelin je bila mlada slikarka s severa Nemčije. Za Almo Karlin je izvedela leta 1929, ko je izšel prvi del Alminega potopisa Samotno potovanje. Zgodba jo je tako očarala, da se je odločila Almo spoznati, zato ji je pisala. Sčasoma sta se spoprijateljili in si v naslednjih letih izmenjali vrsto pisem in obiskov. Leta 1934 se je Thea preselila k Almi v Celje in z njo ostala do njene smrti (Trnovec 2015, 52). 
da zbirko predmetov neevropskega izvora preda takratnemu Mestnemu muzeju Celje (Trnovec 2015, 57; Shigemori Bučar 2017, 219). Del omenjene zbirke je tudi kamen za črnilo, ki je predmet pričujoče raziskave (Slika 1). Kamni za pridobivanje črnila se uporabljajo skupaj s pigmentno paličico in vodo v vseh državah Vzhodne Azije (na Kitajskem, Japonskem in v Koreji) predvsem kot pripomočki pri pisanju kaligrafije in slikarstvu $\mathrm{v}$ tehniki črnila in vode. $\mathrm{V}$ vdolbino na zgornji strani kamna se vlije manjšo količino vode, nato se v vodi ob kamen drgne pigmentna tablica, dokler se ne pridobi zadovoljive konsistence in količine črnila. Pridobivanje črnila je pomemben del postopka pisanja kaligrafije ali slikanja.

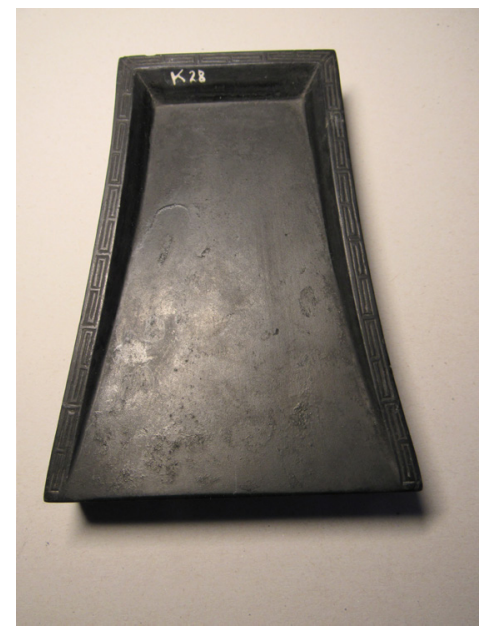

Slika 1: Kamen za črnilo iz Zbirke Alme Karlin (Pokrajinski muzej Celje).

Namen raziskave je skozi študijo predmeta prevrednotiti obstoječe podatke o kraju izvora kamna, glede katerih so se med ponovnim raziskovanjem ter identifikacijo in katalogizacijo predmeta pojavili dvomi. Po podatkih, zapisanih v Inventarni knjigi Zbirke Alme Karlin Pokrajinskega muzeja Celje, je bilo ugotovljeno, da se je kamen uporabljal za pridobivanje črnila, kot kraj izvora pa je bila navedena Japonska. Slednji podatek je vprašljiv iz več razlogov. Prvi je ta, da je osnovne podatke o provenienci predmetov muzeju posredovala dedinja Almine zapuščine. Kustosinja, ki je bila zadolžena za predajo predmetov Mestnemu muzeju Celje med letoma 1957 in 1960, je bila Milena Moškon, ki je o popisovanju predmetov povedala:

$\mathrm{Na}$ mestu prevzema nismo nič dokumentirali, ampak je Thea prihajala $\mathrm{v}$ muzej in pripovedovala, od kod izvira posamezen predmet. Povedala je tudi, da je Alma sama povedala, kaj naj podari muzeju. (Trnovec 2015, 57) 
Ker Thea Schreiber Gammelin ni bila prvotna zbirateljica ali lastnica zbirke, je potovanje okoli sveta poznala zgolj iz Alminih pripovedovanj in zapisov. Njenih podatkov glede imen, uporabe in provenience ne smemo neposredno jemati kot dejstvo. Za več predmetov iz zbirke se je med raziskovanjem namreč že pokazalo, da so njihovi inventarni zapisi vsebovali napačne ali pomanjkljive podatke, ki so bili zapisani na podlagi Theinih osebnih pričevanj.

Poleg nezanesljivih osnovnih podatkov o predmetih sta na prevrednotenje obstoječe identifikacije vplivala tudi opis in pečat na kamnu za črnilo. Prvi zapis je ročno vrezan oziroma vklesan pečat na spodnji strani predmeta (Slika 2). Drugi zapis je ročno zapisan na spodnji strani kamna v vertikalni smeri od zgoraj navzdol. Oba, pečat in ročni zapis, sta potrebna natančne obdelave in prevoda.

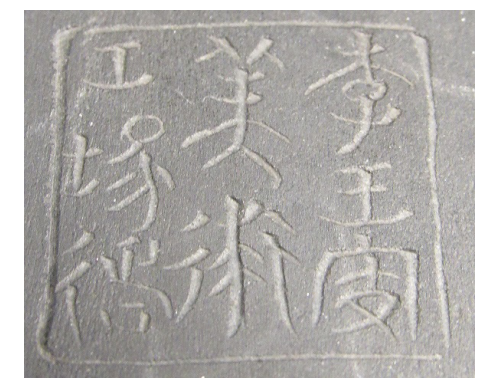

Slika 2: Pečat na kamnu za črnilo (Zbirka Alme Karlin, Pokrajinski muzej Celje).

Cilj pričujoče raziskave je tako s pomočjo podrobne analize, primerjave in prevoda pečata ter ročnega zapisa na spodnji strani kamna za pridobivanje črnila pravilno določiti kraj izvora predmeta. Nato bomo s pridobljenimi podatki poskušali predmet umestiti v ožji časovni okvir nastanka in v širši kontekst Alminega potovanja ter obenem v splošnejši družbenozgodovinski kontekst vzhodnoazijske regije v zgodnjem 20. stoletju.

\section{Kamen za črnilo - opis predmeta}

Kamen za pridobivanje črnila iz zbirke predmetov Alme Karlin je črne barve in nekoliko trapezoidne oblike. $\mathrm{Na}$ zgornjem delu ima pravokotno vdolbino, katere dno se pod rahlim kotom spušča proti zgornji strani kamna. Kamen je dolg 15,1 $\mathrm{cm}$, največja širina je $10,8 \mathrm{~cm}$, najmanjša $8 \mathrm{~cm}$, globok pa je $2,4 \mathrm{~cm}$. Vdolbina na zgornji strani je dolga $13,7 \mathrm{~cm}$, največja širina je $9,2 \mathrm{~cm}$, najmanjša $5,7 \mathrm{~cm}$, na najnižji točki je globoka $1,2 \mathrm{~cm}$. Na zgornji strani je po vsej dolžini roba okoli 
vdolbine izklesan okrasni vzorec $\mathrm{v}$ obliki meandra, ki je po vsej dolžini širok okoli $1,5 \mathrm{~cm}$. Na spodnji strani je prav tako vdolbina, ki je enake oblike kot tista na zgornji strani kamna. $V$ višino meri $13,7 \mathrm{~cm}$, njena največja širina je $8,3 \mathrm{~cm}$, najmanjša pa $4,7 \mathrm{~cm}$. Na najnižji točki je globoka $1 \mathrm{~cm}$.

Manjši ročno vrezan pečat sredi vdolbine na spodnji strani kamna je delno neberljiv. $V$ višino meri 1,7 cm, $v$ širino 1,8 cm in je štirikotne oziroma skoraj kvadratne oblike. Glede na pismenke, ki ga sestavljajo, ga lahko v notranjosti navidezno razdelimo na tri vertikalne pasove enake širine. Od teh sta skrajni levi in skrajni desni vsak horizontalno razdeljena na tri enako velike dele. Srednji navpični pas pa lahko po sredini navidezno razdelimo na dve polovici.

Napis pečata beremo od zgoraj navzdol in od desne proti levi. Sestavlja ga skupno osem različnih pismenk v mali pečatni pisavi. ${ }^{5}$ Zaradi stare oblike pismenk in ročne izdelave je pečat na nekaterih delih težko berljiv, vendar lahko nekatere pismenke prepoznamo brez večjih težav. Brez dodatnih orodij, slikovnega gradiva ali orodij lahko $\mathrm{z}$ osnovnim poznavanjem male pečatne pisave in kitajskih pismenk prepoznamo šest od osmih pismenk. Zapis je naslednji: 李王 [prva manjkajoča pismenka - nejasno] 美術工場 [druga manjkajoča pismenka - nejasno] ali Liwang [prva manjkajoča pismenka - nejasno] meishu gongchang [druga manjkajoča pismenka - nejasno] (Slika 3).

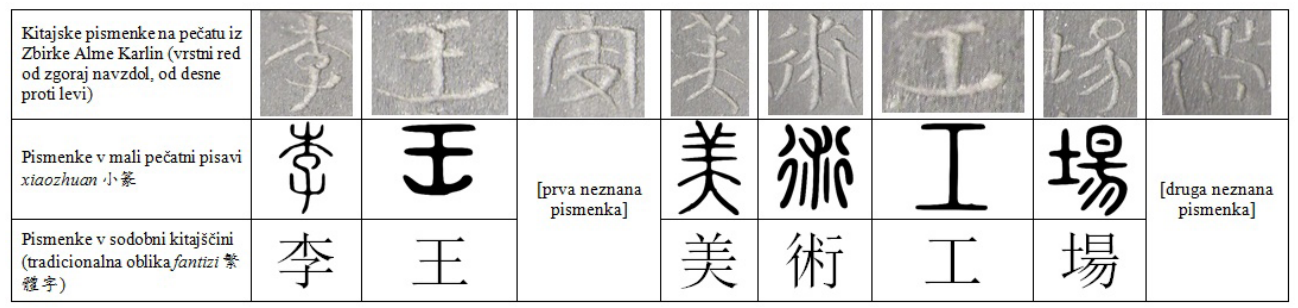

Slika 3: Ponazoritev primerjave pečata s pismenkami male pečatne pisave in sodobno kitajsko pisavo (Zbirka Alme Karlin, Pokrajinski muzej Celje).

5 Najpogostejša pisava, ki se uporablja na pečatih, je pečatna pisava (zhuanshu 管書). Poznamo veliko pečatno pisavo (dazhuan 大管) in malo pečatno pisavo (xiaozhuan 小管). Njuni obliki se razlikujeta, velika pečatna pisava je nekoliko bolj okorna od male. Za časa obdobja Vojskujočih se držav Zhanguoshidai 戰國時代 (475 pr. n. št.-221 pr. n. št.) so uporabljali obe vrsti: veliko pečatno pisavo predvsem na območju takratne države Chu 楚 (1030 pr. n. št.-223 pr. n. št.), uporaba male pečatne pisave pa je prevladovala na vseh ostalih območjih (Sun 2004, 5).

6 Spletni portal Chinese Etymology: pismenka li 李 (slika št. S03959, slovar Shuowen jiezi); pismenka wang 王 (slika št. L32853, slovar Liushutong); pismenka mei 美 (slika št. S02687, slovar Shuowen jiezi); pismenka shu 術 (slika št. L26097, slovar Liushutong); pismenka gong 工 (slika št. S03466, slovar Shuowen jiezi); pismenka chang 場 (slika št. L32738, slovar Liushutong). 
Čez pečat je zapisan tudi navpičen in nekoliko slabše viden, vendar v celoti berljiv ročni napis s svinčnikom v kitajskih pismenkah, ki se glasi 大正十年八月八日 ali Dazheng shinian bayue bari. V prevodu napis nakazuje na specifični datum, in sicer »Deseto leto [obdobja] Taishō, osmi mesec, osmi dan« ali »osmi avgust desetega leta v obdobju Taishō«.

\section{Analiza in pomen ročnega zapisa}

Napis na spodnji strani kamna za kaligrafijo se v smeri od zgoraj navzdol glasi 大 正十年八月八日 (Dazheng shinian bayue bari) in v neposrednem prevodu označuje specifičen datum: osmi avgust desetega leta v obdobju Taishō oz. 8. avgust 1921. Obdobje Taishō ${ }^{7}$ je obdobje v japonski zgodovini, ki je trajalo od leta 1912 do leta 1926. Deseto leto obdobja Taishō je tako leto 1921. Ker napis nakazuje na morebiten japonski izvor predmeta, je primerno, da njegovo transkripcijo podamo tudi v japonskem jeziku, in sicer Taishö jünen hachigatsu hachi nichi (Slika 4 in Slika 5).

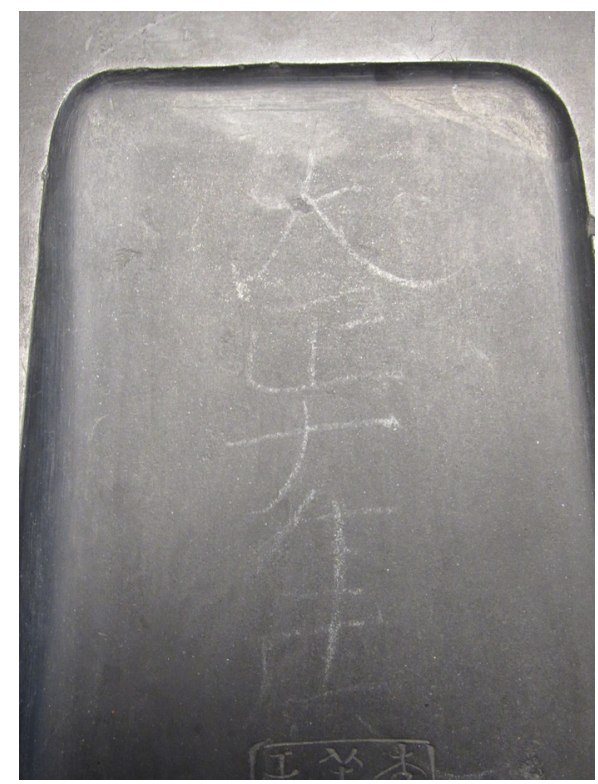

Slika 4: Zgornji del ročnega napisa s svinčnikom na spodnji strani kamna (Zbirka Alme Karlin, Pokrajinski muzej Celje).

7 V tem času je vladal cesar Taishō Taishō tennō 大正天皇 po imenu Yoshihito 嘉仁 (1879-1926), ki je bil 123. japonski cesar (Andressen 2002, 93-99). 


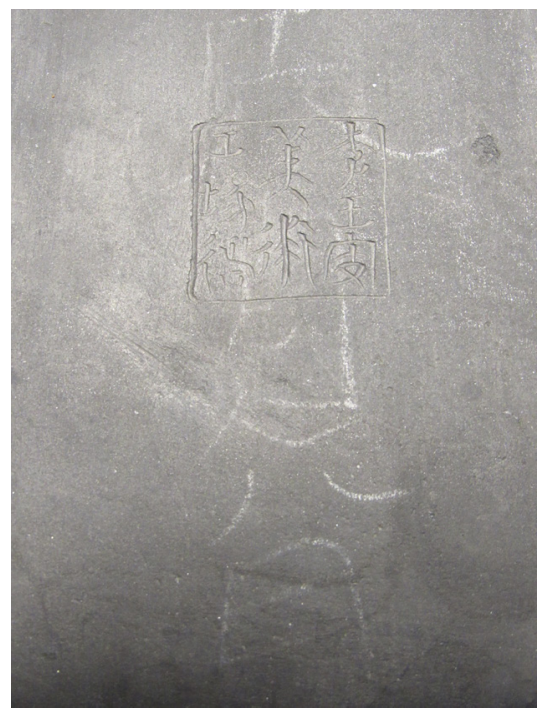

Slika 5: Spodnji del ročnega napisa s svinčnikom na spodnji strani kamna (Zbirka Alme Karlin, Pokrajinski muzej Celje).

Omenjeni ročni zapis prvotno ni bil del predmeta, zaradi pomanjkljivih podatkov tudi ne moremo natančneje določiti avtorstva ali samega namena zapisa. Glede na to, da je zapis napisan površno in sama oblika pismenk nakazuje na nekoliko nerodno oziroma nevajeno roko, obstaja možnost, da ga je zapisala tuja oseba, mogoče celo Alma Karlin. Znano je namreč, da se je na Japonskem učila slikanja, zato je mogoče, da se je urila tudi v pisanju. To sicer ne izključuje možnosti, da je zapis dodala katerakoli druga oseba. Tudi sam kamen bi lahko kupila Alma, lahko bi ga tudi dobila kot darilo. Kljub neznankam pa imamo možnost zapisani datum umestiti v kontekst Alminega potovanja glede na to, kje se je nahajala 8. avgusta 1921. Iz kombinacije podatkov, podanih v potopisu in življenjepisu Alme Karlin, lahko razberemo, da je v obdobju prve polovice avgusta leta 1921 potovala od Mehike (kjer je obiskala mesta Salina Cruz, Acapulco, Manzanillo, Mazatlan) prek Angelskega otoka v zalivu San Francisco do mesta San Francisco, kamor je prispela 15. avgusta 1921 (Trnovec 2015, 32; Karlin 1969, 125-28). Iz njenega potopisa ni mogoče razbrati, da bi se datum 8. avgust 1921 lahko nanašal na specifičen dogodek na poti, ki bi za pisateljico imel kakšen poseben pomen. Od kod izvira ta napis oziroma na kaj se nanaša konkretni datum, zaradi pomanjkanja virov zato težko točno argumentiramo.

V zgodnjih dvajsetih letih 20. stoletja je Alma Karlin sicer prepotovala tudi države Vzhodne Azije. Po območju Japonske, Koreje, Kitajske (s Hongkongom) in Tajvana (takratne Formoze) je potovala približno leto in pol, med začetkom junija 1922 in 
koncem januarja 1924. V tem času je med junijem 1922 in julijem 1923 živela na Japonskem (Trnovec 2015, 30-36). Omeniti je treba zgodovinsko ozadje območja, po katerem je Alma Karlin potovala: Tajvan in Koreja sta bila v tistem času namreč pod japonsko oblastjo. Ozemlje Tajvana je Japonska dobila po podpisu sporazuma v Shimonosekiju leta 1895 ob koncu kitajsko-japonske vojne (1894-1895), oblast nad korejskim ozemljem pa leta 1905 po zmagi v rusko-japonski vojni (1904-1905) s podpisom mirovne pogodbe v Portsmouthu (Hwang 2010, 147; Andressen 2002, 93-96). To je razvidno tudi iz Alminega potopisa, saj je med potovanjem po omenjenih državah opisovala tudi svoje stike $z$ Japonci na okupiranih območjih.

V Samotnem potovanju avtorica ne omenja kamna za črnilo, le naklonjenost do japonskega načina slikanja in svoje učenje le-tega (Karlin 1969, 170). Kljub temu brez dodatnih virov s potovanja ne moremo odgovoriti na vprašanje, kaj je bil dejanski namen zapisanega datuma in kdo je zares njegov avtor. Lahko zgolj sklepamo, da je datum najverjetneje imel poseben oz. določen pomen za avtorja in da zaradi takratnih razmer $\mathrm{v}$ regiji obstaja verjetnost, da je bil datum zapisan na Japonskem, v Koreji ali na Tajvanu.

Obenem je treba omeniti, da lahko dodatni napisi, kot je bil obravnavani, zavajajoče vplivajo na določitev izvora predmeta, kar lahko vodi k napačnim zaključkom. Čeprav napis jasno podaja datum iz obdobja japonske zgodovine, to še ne pomeni, da je kraj izvora kamna Japonska, saj je bil napis dodan pozneje. Razumevanje samega napisa pečata je tako - v razmerju do ročnega zapisa - primarnega pomena.

\section{Analiza in pomen vrezanega pečata}

Za dokončno potrditev izvora predmeta je ključno raziskovanje pečata na spodnji strani kamna. Iz berljivega dela pečata smo razbrali pismenko li (李 li), ki je eden od najbolj razširjenih priimkov, nekoga ali nekaj kraljevega (王 wang), umetnost (美術 meishu) in delavnico (工場 gongchang) oz. umetniško delavnico (美術工 場 meishu gongchang). Pismenki v spodnjem desnem in spodnjem levem kotu sta nejasni oz. težko berljivi zaradi nejasnega zapisa.

Način, kako lahko pridemo do informacij, ki bi nam pomagale razvozlati napis pečata, je iskanje slik podobnih pečatov na drugih izdelkih ali pečatov istega izdelovalca. Danes nam takšno iskanje omogočajo in tudi močno olajšujejo različni spletni brskalniki, ki imajo funkcijo iskanja slikovnega gradiva po določenem geslu. V tem primeru nam pomaga že samo delno poznavanje pečata. $Z$ vsakim vnosom gesla oziroma ključnih besed sicer dobimo veliko zadetkov in potrebnega je veliko časa, da jih pregledamo in izločimo tiste, ki bi nam potencialno lahko pomagali pri raziskavi. S tem lahko pridemo do bolj specifičnih rezultatov tako slikovnega kot tudi 
ostalega, za naše raziskovanje relevantnega gradiva. Ta pristop je lahko zelo učinkovit tudi pri raziskovanju najrazličnejših javno dostopnih spletnih arhivov slikovnega gradiva. Omenjeni princip raziskovanja nam je lahko v veliko pomoč pri problematiki berljivosti pečatov in raziskovanju včasih zapletene etimologije posameznih kitajskih pismenk. S pomočjo dela pečata, ki je bil razpoznaven oziroma berljiv, je bila tako s spletnimi brskalniki najdena slika pečata, ki je bil zelo podoben pečatu na kamnu za pridobivanje črnila iz Zbirke Alme Karlin (Slika 6). Omenjena slika je bila objavljena na japonskem osebnem blogu v sklopu dnevniškega zapisa iz leta 2014 uporabnika s psevdonimom Toyopika. Ta na novo najdeni pečat je bil tudi $\mathrm{v}$ celoti berljiv, kar omogoča rekonstrukcijo zapisa na pečatu, ki je predmet raziskave.

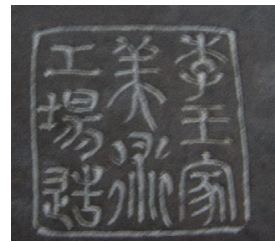

Slika 6: Pečat iste delavnice na drugem kamnu za pridobivanje črnila (Toyopika 2014).

V besedilu dnevniškega zapisa je avtor (ali avtorica) pisal o učenju kaligrafije, nakupu kaligrafskega kamna in pečatu, ki je bil na njem. Prav tako je trdil, da je pečat na kamnu pravzaprav pečat izdelovalca in da kamen za kaligrafijo ne izvira iz Japonske ali Kitajske, pač pa iz Koreje (Toyopika 2014). Najdba tega zapisa na blogu in slike, vključene v besedilo, je bila ključnega pomena za pričujočo raziskavo, saj sta bili skozi nadaljnje primerjanje in analizo pismenk odkriti podobi in pomena dveh neznanih oziroma neberljivih pismenk na prvotnem pečatu (Slika 7).

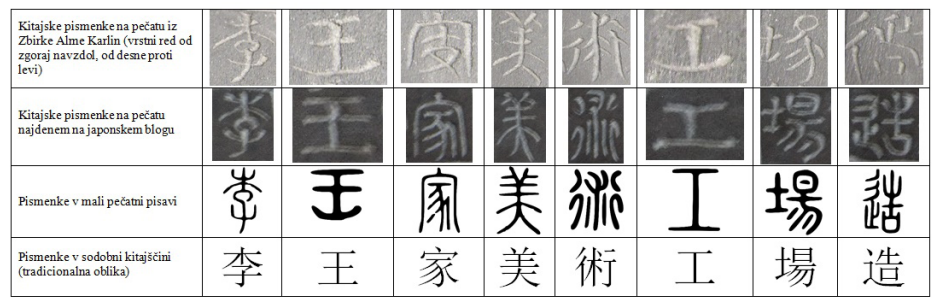

Slika 7 Ponazoritev dveh pečatov s pismenkami male pečatne pisave in sodobno kitajsko pisavo ${ }^{8}$ (Zbirka Alme Karlin, Pokrajinski muzej Celje; Toyopika 2014).

8 Spletni portal Chinese Etymology: pismenka li 李 (slika št. S03959, slovar Shuowen jiezi); pismenka wang 王 (slika št. L32853, slovar Liushutong); pismenka jia 家 (slika št. S05205, slovar Shuowen

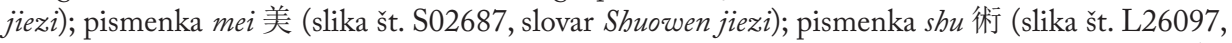
slovar Liushutong); pismenka gong I (slika št. S03466, slovar Shuowen jiezi); pismenka chang 場 (slika št. L32738, slovar Liushutong) pismenka zao 造 (slika št. S01239, slovar Shuowen jiezi). 


\section{Analiza prve neznane pismenke}

Primerjava in analiza sta pokazali, da je prva neznana oziroma nejasna pismenka v pečatu kitajska pismenka jia 家, ki pomeni »družina«, vendar se v napisu pečata na kamnu iz Zbirke Alme Karlin pojavi v popolnoma drugačni obliki. Druga neznana pismenka je pismenka zao 造, ki pomeni »izdelano« ali »narediti«, vendar se tudi ta pojavi v drugačni obliki, poleg tega pa je zelo nejasno zapisana in posledično pravzaprav neberljiva. Vzroke za drugačen zapis moramo iskati v etimološkem razvoju omenjenih kitajskih pismenk, predvsem njunih oblik v času, ko je bila uporaba pečatne pisave močno razširjena. V dinastiji Qin 秦 (221-206 pr. n. št.) je pod prvim kitajskim cesarjem Qinshijem 秦始皇帝 (221-210 pr.n. št.) prišlo do poenotenja pisave. Takrat so določene pismenke že imele več različnih oblik, ki so se s časom spreminjale. Zaradi regionalnosti je posledično obstajalo več različnih oblik določenih pismenk v različnih časovnih obdobjih; nekatere izmed njih so ostale v uporabi tudi po poenotenju pisave. To pomeni, da obstaja možnost, da so se še vedno uporabljale tudi v napisih pečatov, kar še danes otežuje branje starejših tekstov, prav tako ni bilo jasnih pravil o tem, kako naj bi bile pismenke zapisane, kateri del je zapisan na levi oziroma na desni (Wei 2014, 38-39). Mala pečatna pisava, katere uporabo so z reformo uvedli po celotnem območju takratne združene Kitajske, je tako izpodrinila vse ostale oblike pismenk, ki so se regionalno uporabljale zgolj na manjših območjih, in postala predhodnica današnje standardizirane oblike kitajske pisave (Norman 1988, 63).

Etimološka analiza pismenke jia 家 razkrije, da sta bili skozi zgodovino Kitajske v uporabi vsaj dve precej različni obliki. Glede na kitajski etimološki slovar Shuwen jiezi $i$ 說文解字 ${ }^{9}$ iz obdobja Poznega Hana je oblika omenjene pismenke predstavljala podobo svinje $s h i$ 豕, ki se nahaja pod streho mian 'i (Shuowen jiezi 2015). Iz njene oblike na obravnavanem pečatu lahko razberemo zgolj obliko strehe zgoraj, spodnji del pa je popolnoma drugačen. Ta pravzaprav ustreza podobi poenostavljene pismenke zhi 支, ki se uporablja tudi danes in v prevodu pomeni "veja« ali "podpora«, a njene oblike ne najdemo v kombinaciji s sestavnim delom pismenke, ki ponazarja streho. $V$ iskanju povezave med tema različnima oblikama pismenke je treba raziskati tudi etimologijo pismenke zhi 支. Slovar Shuowen v tem primeru ponudi razlago, da je oblika te pismenke predstavljala podobo desne roke you 又, ki drži bambusovo palico cao 屾 (Shuowen jiezi 2015). Etimološki pomen s tem razkrije, da podoba pismenke dobesedno predstavlja roko, ki drži

9 Shuowen jiezi $i$ 說文解字 (skrajšano Shuowen) je eden najstarejših in najpomembnejših slovarjev, ki razlagajo pomene in etimologijo kitajskih pismenk. Prvič je bil zbran in urejen v obdobju Pozni Han (Houban 後漢), ki obsega skoraj dve stoletji (25-220 n. št.). 
palico pod streho. Slovar Liushutong 六書統 ${ }^{10}$ iz časa dinastije Yuan pa razkrije, da se je pismenka jia 家 v mali pečatni pisavi pojavljala ravno v omenjeni obliki, torej v obliki roke, ki pod streho drži palico (Sears 2013). S primerjavo etimološkega razvoja dveh različnih oblik pismenk, ki se pojavljata na dveh različnih pečatih, tako lahko sklepamo, da gre za različni obliki iste pismenke (Slika 8).

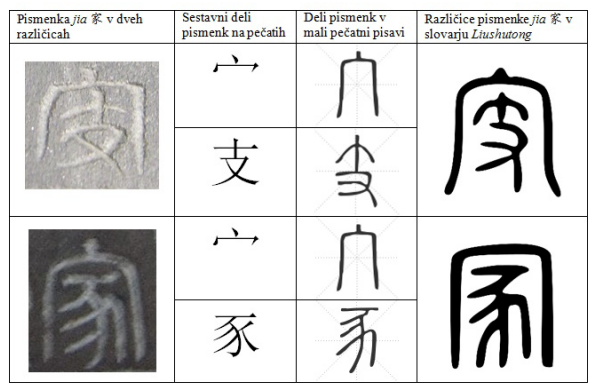

Slika 8: Dve razlicni obliki pismenke jia 家 in njuno različno poenostavljanje ${ }^{11}$ (Zbirka Alme Karlin, Pokrajinski muzej Celje; Toyopika 2017).

Čeprav je zgornji del obeh pismenk ostajal enak, sta bila spodnja dela različna. Iz tega razloga se je vsaka oblika pismenke poenostavljala v svojo smer, medtem ko je sam pomen obeh ostal enak. Postopoma se je v uporabi ustalila ena od obeh oblik, uporaba druge pa je bila počasi opuščena in je sčasoma postala težko berljiva oziroma nerazpoznavna. Pri raziskovanju je tako ključno poznavanje etimološkega razvoja pismenk in njihovih oblik v preteklih obdobjih. Samo tako lahko pridemo do zaključka, da gre pravzaprav za isto pismenko v dveh različnih oblikah.

\section{Analiza druge neznane pismenke}

Iz primerjave obeh pečatov je razvidno tudi, da je druga neznana pismenka zao 造, ki v prevodu pomeni »narediti« ali "zgraditi«. V rahlo spremenjeni obliki se pojavi radikal $c h u o$ 之, ki pomeni »korak«. Zapisan je v obliki radikala $c h i$ 彳, ki sicer nosi enak pomen, vendar oblikovno spremeni podobo celotne pismenke. Pred strogo določitvijo pravil za zapisovanje pismenk in poenotenjem pisave se je radikal chuo 之 namreč pojavljal v več različnih oblikah. Tako se je v oblikah chuo 之, chi 彳,

10 Liushutong 六書統 je delo oziroma slovar kitajskih pismenk, napisan v času dinastije Yuan 元 (1279-1368), avtor je bil učenjak Yang Huan 楊桓.

11 Slovar Shuowen jiezi, spletni portal Chinese Etymology: pismenka jia 家 (slika št. L08797, slika št. L08806, slovar Liushutong). 
chuo 定 in zhi 止 izmenjaje pojavljal na istem mestu pri istih pismenkah (Sears 2013). Na podlagi teh zaključkov lahko sklepamo, da kot v primeru raziskane pismenke jia oblika pismenke zao 造 s prvotnega pečata iz zbirke predmetov Alme Karlin najverjetneje izvira iz časa pred poenotenjem pisave, ko se je kljub enotnemu pomenu del pismenke (radikal) zapisoval v različnih oblikah.

Pri drugem delu pismenke, fonetiku gao 告, je bila edina problematika popolna neberljivost, saj je bil zapisan $z$ veliko avtorske umetniške svobode. Ta del pismenke se je, $v$ nasprotju $\mathrm{z}$ radikalom, razjasnil zgolj s primerjavo pečatov na dveh kamnih za črnilo. Oblika pismenke zao 造, in s tem tudi njenega fonetika, je bila na najdeni fotografiji z japonskega bloga povsem jasna. $\mathrm{Na}$ podlagi primerjave slikovnega gradiva se je s tem povsem rekonstruirala tako celotna oblika pismenke kot tudi podoba pečata na predmetu iz Zbirke Alme Karlin. V tem primeru bi bilo zgolj s poznavanjem sodobne kitajske pisave in osnov etimologije pismenk nemogoče razbrati pravo obliko in pomen zapisa oziroma pismenke na kamnu, ki je predmet raziskave.

$\mathrm{S}$ pomočjo zgoraj prikazanega raziskovalnega postopka je bilo ugotovljeno, da zapis 李王家美術工場造 ali Liwangjia meishu gongchang zao pomeni »Izdelano v umetniški delavnici kraljeve družine Li«. Ker gre za pečat specifične umetniške delavnice oz. obrtniške ustanove in ne kraljeve družine same, lahko potrdimo, da gre za pečat iz vrste zasebnih pečatov in podvrste studijskih pečatov. V celoti razvozlan napis pečata vzpostavi temelje za nadaljnje raziskave o pomenu in vlogi predmeta in s tem pravilne umestitve predmeta $\mathrm{v}$ družbenopolitične okvire posameznih regij.

\section{Utemeljitev in potrditev izvora kamna za črnilo iz Zbirke Alme Karlin}

Razširjena uporaba kitajskih pismenk v vzhodnoazijskem prostoru pod vprašanje postavi izvor predmeta, na katerem je pečat, in posledično izvor samega pečata. Če se je ista pisava vsaj v določenem časovnem obdobju uporabljala v vseh omenjenih državah in če je prav tako razširjena uporaba enakega stila pečatov, potem moramo najprej razvozlati pomen celotnega zapisa. Samo tako lahko pečat z nadaljnjim raziskovanjem pravilno časovno in prostorsko umestimo, ga pravilno razberemo in njegovo vsebino razumemo v kontekstu specifičnega kulturnega okolja.

Kljub ročnemu zapisu, ki izpostavlja specifični datum iz obdobja japonske zgodovine, pa kraj nastanka s tem nikakor ni potrjen. Zapis na že omenjenem japonskem blogu je namreč kot kraj izvora izpostavil Korejo (Toyopika 2014). Prav tako lahko dvome o geografski umestitvi predmeta vzbudi razširjenost priimka Li李 v državah Vzhodne Azije. Ta namreč izvira iz Kitajske, $\mathrm{z}$ isto pismenko pa 
se pojavlja še v Koreji (v latinizirani transkripciji $L i, L e e, Y i, I$ in $R i$ ) in Vietnamu (v latinizirani transkripciji $L y$ ). Priimek Li se v nasprotju s Korejo in Vietnamom ne uporablja na Japonskem, zato obstaja zelo malo možnosti, da bi se umetniška delavnica s tem imenom pojavila $\mathrm{v}$ tej državi.

Posledično je bilo ugotovljeno, da omenjena »kraljeva družina Li« (李王家 Liwangjia) izvira iz Koreje, saj je bil Li priimek kraljevske družine zadnje korejske dinastije Joseon (Hangul: Choson 대조선국; Hanja: 大朝鮮國) med letoma 1392 in 1897 ter Korejskega imperija (Hangul: Daehan Jeguk 대한제국; Hanja: 大韓帝國) med letoma 1897 in 1910 . Leta 1910 je Koreja postala kolonija Japonskega imperija Dai Nippon Teikoku 大日本帝國 (1868-1947), predstavniki kraljeve družine Li pa so dobili naslov korejskih plemičev (Chōsen kizoku 朝鮮貴族) (Young 2000, 17-26). ${ }^{12}$ Najbolj pogosto se predmeti s tem pečatom pojavljajo na japonskih spletnih dražbah, manjše število tudi na korejskih in kitajskih. Večkrat znotraj opisa predmetov te delavnice zasledimo tudi japonski napis Chousen bijut$s u$ 朝鮮美術, ki pomeni »umetnost Joseon« oz. »korejska umetnost«. Še en znak, ki nakazuje, da izvor predmetov omenjene delavnice ni Japonska, pač pa po vsej verjetnosti Koreja.

$\mathrm{Na}$ nekaterih pečatih iste delavnice se poleg imena delavnice pojavlja tudi napis jingcheng 京城. To je bilo v času japonske okupacije Koreje med letoma 1910 in 1945 uradno ime mesta Seul (kor.: Seul 서울), ki je danes prestolnica Južne Koreje. V času pod japonsko nadvlado je bilo mesto preimenovano v Keijō 京 城 (kor.: Gyeongseong). To potrdi, da se je delavnica, iz katere izhaja obravnavani pečat, nahajala v Seulu v času med letoma 1910 in 1945 . Iz tega smo razbrali natančno geografsko umestitev kamna za pridobivanje črnila, na katerem se nahaja obravnavani pečat; pečat se je uporabljal na izdelkih Umetniške delavnice kraljeve družine Li v Seulu na območju današnje Južne Koreje v prvi polovici 20. stoletja.

$\mathrm{Na}$ podlagi teh podatkov lahko z obdobjem med letoma 1910 in 1945 določimo tudi natančnejši časovni okvir izdelave predmeta. Za bolj specifično časovno umestitev je treba raziskati še delovanje omenjene delavnice. Po priključitvi korejskega ozemlja Japonski je na Japonskem začelo rasti zanimanje za tradicionalno korejsko umetnost in različne izdelke. S tem razlogom je bila leta 1908 ustanovljena tudi Umetniška delavnica Hanseong (Hanseong misul pumjejagso 한성미술품제작소). Njen glavni namen je bil izdelava umetniških izdelkov v podobi tradicionalne korejske umetnosti za izvoz in prodajo na Japonskem. Delavnico je ustanovil korejski dvor, zato je ta po letu 1911 tudi nosila ime Umetniška delavnica kraljeve družine

12 Koreja je pod japonsko oblastjo ostala do leta 1945. 
$\mathrm{Li}$ (Liwang ga misul gongjangjo 이 왕가미술공장조). Pod novim imenom je delovala med letoma 1911 in 1922 (Han in Kim 2013, 397). Vsi izdelki, ki nosijo pečat $\mathrm{s}$ tem imenom, so bili torej narejeni $\mathrm{v}$ časovnem obdobju enajstih let, ko je delavnica delovala pod tem imenom. Napis, ki sestavlja pečat, je zapisan v pisavi Hanja oziroma kitajskih pismenkah, ki jih je Koreja prevzela iz kitajske pisave.

\section{Zaključek}

$Z$ raziskovanjem ročnega zapisa, pečata in etimološkega razvoja pismenk je bila uspešno določena in potrjena tako prostorska kot tudi natančnejša časovna umestitev predmeta. Kot država izvora predmeta je do podrobnejše analize veljala Japonska, vendar so v pričujoči raziskavi predstavljeni argumenti, ki potrjujejo, da kamen za pridobivanje črnila iz Zbirke Alme Karlin izvira iz Koreje, natančneje iz mesta Seul (današnje prestolnice Južne Koreje). Skozi celostno analizo pečata in s podrobnim raziskovanjem etimološkega razvoja kitajskih pismenk je bilo ugotovljeno, da je bil predmet raziskave izdelan v Umetniški delavnici kraljeve družine Li, z nadaljnjim raziskovanjem imena delavnice pa je bilo čas izdelave mogoče umestiti v natančnejši časovni okvir, v desetletje med letoma 1911 in 1922 . Na podlagi informacij o omenjeni delavnici je bil kamen iz Zbirke Alme Karlin najverjetneje produkt težnje po večjem proizvajanju korejske umetnosti s tradicionalnimi značilnostmi v Koreji. S tem se je po eni strani ohranjala tradicija, po drugi pa so z izvažanjem in prodajo umetniških izdelkov zadovoljili zahtevni japonski trg.

Kljub pričujoči raziskavi ter prebiranju potopisa Alme M. Karlin in knjige o njenem življenju in delu še vedno ni znano, kje je Alma Karlin dobila ali kupila ta kamen. Glede na to, da je na Japonskem preživela največ časa, se tam aktivno učila japonskega načina slikanja in se družila $\mathrm{z}$ japonskimi umetniki ter bila $\mathrm{v}$ razmeroma dobrem ekonomskem položaju, obstaja večja verjetnost, da je kamen dobila ali kupila na Japonskem. Drugi argument bi bila že omenjena velika prisotnost korejskih umetniških izdelkov na japonskem trgu v času njenega potovanja. Povezava z Japonsko ostaja zelo verjetna tudi zaradi ročnega zapisa na predmetu, ki pomeni specifični datum v obdobju japonske zgodovine, imenovanem Taishō, ni pa jasno, kaj ta datum označuje. 


\section{Viri in Literatura}

Andressen, Curtis. 2002. A Short History of Japan: From Samurai to Sony. Crow's Nest: Allen \& Unwin.

Han, Seokwoo in Younhwa Kim. 2013. Thesis Comprehension and Methodology Study. Giungido: Jigu Publishing co.

Hwang, Kyung-Moon. 2010. A History of Korea: An Episodic Narrative. Hampshire, New York: Palgrave Mcmillan.

Karlin, Alma M. 1969. Samotno potovanje. Ljubljana: Mladinska knjiga.

Kim, Yongna. 2005. 20th Century Korean Art. London: Laurence King Publishing. Kong, Yunbai 孔雲白. 1936. Zhuanke rumen 管刻入門 (Vrezovanje pečatov za začetnike). Shanghai: Shanghai Book Publishings.

Lee, Ji-young. 2013. The Understanding Korea Series: Hangeul. Haogae-ro, Bundang-gu, Seongnam-si, Gyeonggi-do: Academy of Korean Studies Press.

Norman, Jerry. 1988. Chinese. New York: Cambridge University Press.

Sears, Richard. 2013. »Chinese Etymology.« Dostop 3. junij 2017. http://chineseetymology.org/CharacterEtymology. aspx?characterInput=\%E8\%BB\%8A\&submitButton1=Etymology.

Shigemori Bučar, Chikako. 2017. »Zbirke starih japonskih razglednic v Republiki Sloveniji.«Asian Studies 5(2): 203-25.

Shuowen jiezi 說文解字. 2015.»Shuowen jiezi - Zhuanshu zidian 說文解字-管 書字典 (Shuwen Jiezi - Slovar pečatne pisave).« Dostop 3. junij 2017. http:// www.shuowen.org.

Sun, Weizu. 2004. Chinese Seals: Carving Authority and Creating History. San Francisco: Long River Press.

Toyopika. 2014. »Suzuri mo sukida 硯も好きだ (V̌̌eč so mi tudi kamni za pridobivanje črnila).« Toyopika no burogu Toyopika のブログ (Toyopikin blog) (blog). 28.6.2014. Dostop 14. april 2017. https://blogs.yahoo.co.jp/tan9uzo9/32901987.html.

Trnovec, Barbara. 2015. Kolumbova hči: življenje in delo Alme M. Karlin. Celje: Pokrajinski Muzej Celje.

Wei, Bi. 2014. "The Origin and Evolvement of Chinese Characters." Gdańskie Studia Azji Wschodniej 4 (1): 33-43.

Young, Ick Lew. 2000. Brief History of Korea; A Bird's-Eye View. New York: The Korea Society. 